\title{
THE IMPACT OF COVID-19 ON EUROPEAN FINANCIAL MARKETS: AN EMPIRICAL ANALYSIS
}

\author{
Margarida Bagão ${ }^{1}$ \\ Rui Dias ${ }^{2}$ \\ Paula Heliodoro ${ }^{3}$ \\ Paulo Alexandre ${ }^{4}$
}

DOI: https://doi.org/10.31410/LIMEN.2020.1

\begin{abstract}
The fast spread of coronavirus (COVID-19) had negative impacts on financial markets worldwide. It created uncertainty and a lack of confidence, causing unprecedented levels of risk, causing sharp losses to investors in a very short period. In view of these events, this essay aims to investigate the relationship between Covid-19 (confirmed cases and deaths), and the stock market indexes of Greece (ATG), France (CAC40), Germany (DAX 30), United Kingdom (FTSE 100), Italy (FTSE MID), Spain (IBEX 35), Ireland (ISEQ), and Portugal (PSI 20), from December 31st, 2019 to July 23rd, 2020. In order to achieve such an analysis, we want to validate if: the increase in cases and deaths resulting from Covid-19 have any connection with the financial markets under analysis? If so, do these connections cause shocks in European financial markets? The results suggest structure breaks, mostly, in March 2020. Covid-19 data (confirmed cases) integrate with the Covid-19 data series (deaths), with the Spanish market (IBEX 35), Greece (ATG), and Italy (FTSE MID). However, the Covid-19 data series (deaths), is synchronized with the Covid-19 data (confirmed cases), with the markets of Germany (DAX 30), France (CAC 40), Ireland (ISEQ), Italy ( FTSE MID), United Kingdom (FTSE 100) and Portugal (PSI 20), just does not synchronize with the Greek market (ATG). We can easily see that the Covid-19 data series (deaths) has a major impact on Europe's financial markets. The results of the VAR Granger Causality / Block Exogeneity Wald Tests model suggest 2 bidirectional causal relationships between confirmed cases and deaths from the Covid-19 virus. However, there were no shocks between Covid-19 data (confirmed cases and deaths) and the financial markets under analysis. As a final discussion, we consider that investors should avoid investments in the stock exchange, at least while this pandemic lasts, and rebalance their portfolios in hedging and/or sovereign debt assets, to mitigate risk and improve the efficiency of their portfolios.
\end{abstract}

Keywords: Covid-19 Coronavirus, Stock markets, Epidemic.

\section{INTRODUCTION}

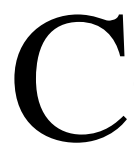

oronavirus Covid-19 is a type of outbreak that first appeared in December 2019 in the city of Wuhan, Hubei province, China. It was declared a pandemic by the World Health Organization (WHO) on March 12, 2020. According to the World Health Organization,

\footnotetext{
Escola Superior de Ciências Empreasarias, Instituto Politécnico de Setubal, Portugal Escola Superior de Ciências Empreasarias, Instituto Politécnico de Setubal \& CEFAGE, Universidade de Évora, Portugal

Escola Superior de Ciências Empreasarias, Instituto Politécnico de Setubal, Portugal Escola Superior de Ciências Empreasarias, Instituto Politécnico de Setubal, Portugal
} 
the number of people infected by Covid-19 worldwide, since the beginning of the pandemic, has already exceeded, on 23rd July 2020, 15.3 million (cases), and 627,000 deaths.

The Covid-19 pandemic negatively affects the global economy, as well as social and cultural life on a global scale. Rating agencies such as Moody's and Standard \& Poors have restricted China's growth forecast for 2020. In line with all these negative effects, it seems inevitable that economic growth and financial markets have also been affected equally (Liu, Manzoor, Wang, Zhang and Manzoor, 2020).

Financial instability is a very important factor for society since a financial crisis or stock market crash can affect, directly or indirectly, the level of the economic well-being of the inhabitants of a country. If a given stock market is strongly linked to the stock market of another country, the financial stability of the first depends, in part, on the financial stability of the second. Thus, the occurrence of integration between markets can have significant implications for the international diversification of risk (Alexandre, Dias, and Heliodoro, 2020a, 2020b; Alexandre, Heliodoro, and Dias, 2019; Dias et al., 2020; Dias and Carvalho, 2020; Dias, Heliodoro, and Alexandre, 2020, 2019; Dias, Heliodoro, Alexandre, Santos, and Farinha, 2021; Dias, Heliodoro, Alexandre, and Vasco, 2020b, 2020a; Dias, Heliodoro, Teixeira, and Godinho, 2020; Dias, Pardal, Teixeira, and Machová, 2020; Dias and Pereira, 2021; Heliodoro, Dias, and Alexandre, 2020; Pardal, P., Dias, R., Šuleř, P., Teixeira, N., and Krulický, 2020).

This study aims to analyze the relationship between Covid-19 (cases and deaths), and stock market indexes in Greece (ATG), France (CAC40), Germany (DAX 30), United Kingdom (FTSE 100), Italy (FTSE MID), Spain (IBEX 35), Ireland (ISEQ), and Portugal (PSI 20), in the period from December 31st, 2019 to July 23rd, 2020. In order to achieve such an analysis, it is intended to verify whether: do the increase in cases and deaths resulting from Covid-19 have any connection with the financial markets under analysis? If so, do these connections cause a stir in Europe's financial markets? The results suggest the existence of synchronizations between the increase in confirmed cases and deaths resulting from the Covid-19 virus, and between these, and the financial markets. However, when we analyze the shocks, we see the absence of unidirectional or bidirectional causalities between the evolution of Covid-19, and the financial markets of Europe.

This investigation differs from studies carried out so far on the impact of the global pandemic on financial markets, as far as is known; the authors Ali, Alam, and Rizvi (2020), Ashraf (2020), Liu, Manzoor, Wang, Zhang and Manzoor (2020), Zeren and Hizarci (2020) analyzed the pandemic shocks, but the research questions, the markets analyzed, and the approach was essentially different from the one followed in this article.

In terms of structure, this article is organized into 5 sections. In addition to the current introduction, section 2 presents a Literature Review with regard to articles on the impact of the global pandemic on international financial markets, section 3 describes the methodology and data, section 4 contains the results. Section 5 presents the general discussions of the work.

\section{LITERATURE REVIEW}

The understanding of international connections between financial markets in periods of the financial crisis is relevant for investors, fund managers and academics, in different aspects, namely in the theme of portfolio diversification (Lee, 2017). 
Özer, Kamışlı and Kamışlı (2016), Jawadi, Chlibi and Cheffou (2019) Moagar-Poladian, Clichici and Stanciu (2019), Salisu, Ndako, Adediran and Swaray (2020) analyzed the movements and the integration between several international markets. Özer, Kamışlı e Kamışlı (2016) analyzed the movements between the markets of Germany, Austria, Czech Republic, Croatia, Lithuania and Greece, the authors show mixed results when failing to show movements. These findings have relevant implications for international investors, portfolio managers and policy makers. Jawadi, Chlibi e Cheffou (2019) studied the movements between the US market and the G-6, BRIC's and MENA markets. The authors show that the MENA and BRIC's markets are segmented with the North American market, while the G-6 markets show integration with the USA. Moagar-Poladian, Clichici and Stanciu (2019) demonstrate that Central and Eastern European markets have robust levels of integration during the European financial crisis. Salisu, Ndako, Adediran and Swaray (2020) analyzed integration into Islamic markets and show that markets are integrated and that this behavior can be influenced by global economic conditions.

Ali, Alam, and Rizvi (2020), Ashraf (2020), Liu, Manzoor, Wang, Zhang and Manzoor (2020), Zeren and Hizarci (2020) analyzed the impact of the global pandemic (Covid-19) on financial markets. Ali, Alam, and Rizvi (2020) investigated the reaction of financial markets as the Coronavirus epicenter moved from China to Europe and then to the USA. The results suggest that China's (initial) epicenter tends towards stabilization, while global markets have entered a free fall, especially in the contagion phase (later). Ashraf (2020) examined the stock markets' response to the Covid-19 pandemic, for this purpose used the daily data from COVID-19 (confirmed cases and deaths) and the profitability of 64 markets, from January 22nd, 2020 to April 17th, 2020. The author shows that the stock markets reacted negatively to the growth of confirmed cases of COVID-19. It means that the returns on the stock markets decreased as the number of confirmed cases increased. Liu, Manzoor, Wang, Zhang and Manzoor (2020) studied the impact of the coronavirus outbreak on 21 stock market indices. The authors show significant structural breaks resulting from the COVID-19 outbreak. Zeren and Hizarci (2020) analyzed the effects of the Covid-19 epidemic on the stock markets in the period from 23rd January 2020 to 13th March 2020. The authors show that the global cases of the outbreak have cointegration relations with the SSE, KOSPI and IBEX35 markets, but not with the FTSE MIB, CAC40, DAX30 markets.

To summarize, this work aims to contribute to the provision of information to investors and regulators in Europe's stock markets, where individual and institutional investors seek diversification benefits, as well as helping to promote the implementation of policies that contribute to the efficiency of these markets. Therefore, the objective of this work is to examine, the synchronizations, and the unidirectional and bidirectional causalities, between the Covid-19 data series (confirmed cases and deaths), and the European financial markets.

\section{METHODOLOGY}

\section{DATA}

The analyzed data are related to the Covid-19 data series (confirmed cases and deaths), and to the stock market indexes of Greece (ATG), France (CAC40), Germany (DAX 30), United Kingdom (FTSE 100), Italy (FTSE MID), Spain (IBEX 35), Ireland (ISEQ) and Portugal (PSI 20), from December 31st, 2019 to July 23rd, 2020. The time series have daily scales and were obtained from the Thomson Reuters platform, with regard to the prices index of the financial markets, they are in local currency, to mitigate distortions in exchange rates. 
Table 1. The name of countries and their indices used in this paper

\begin{tabular}{|c|c|}
\hline Index & Country \\
\hline ATG & Greece \\
\hline CAC 40 & France \\
\hline DAX 30 & Germany \\
\hline FTSE 100 & United Kingdom (UK) \\
\hline FTSE MID & Italy \\
\hline IBEX 35 & Spain \\
\hline ISEQ & Ireland \\
\hline PSI 20 & Portugal \\
\hline
\end{tabular}

Source: Own elaboration

\section{METHODOLOGY}

The development of the research took place over several stages. The characterization of the sample used was carried out through descriptive statistics, from the adherence test of Jarque and Bera (1980), as well as graphics of stability to the residues. To estimate the structural breaks in the financial markets, we used the unit root test of Clemente et al. (1998). To assess the integration between the Covid-19 data series (confirmed cases and deaths), and the financial markets in Europe, we use the Gregory and Hansen (1996) that identifies structure breaks. To examine the significance of the causal relationships between the Covid-19 data series, and the financial markets, in analysis, we used the VAR Granger Causality / Block Exogeneity Wald Tests model, which uses Wald's statistic, which tests whether the null hypothesis that the coefficients of the lagged endogenous variables of the variable "cause" are null or not "cause" in the Grangerian sense the dependent variable. However, it should be noted that the result of this test is highly sensitive to the number of lags considered in the model, so the first concern is to properly estimate this value, in order to arrive at robust evidence (Gujarati, 2004). Besides, and to determine the number of lags to include in the causality tests, we use the HQ (HannanQuinn information criterion) criterion, and to assess the robustness of the model we apply the VAR Residual Serial Correlation LM Tests.

\section{4.`RESULTS}

Figure 1 shows the evolution of the Covid-19 pandemic in the number of confirmed cases, as well as deaths, in a global context. As of July 23, 2020, confirmed cases had already exceeded 15.3 million, and deaths had already exceeded 627,000.

Figure 1. Evolution of the Covid-19 pandemic, from 12/31/2019 to 7/23/2020.

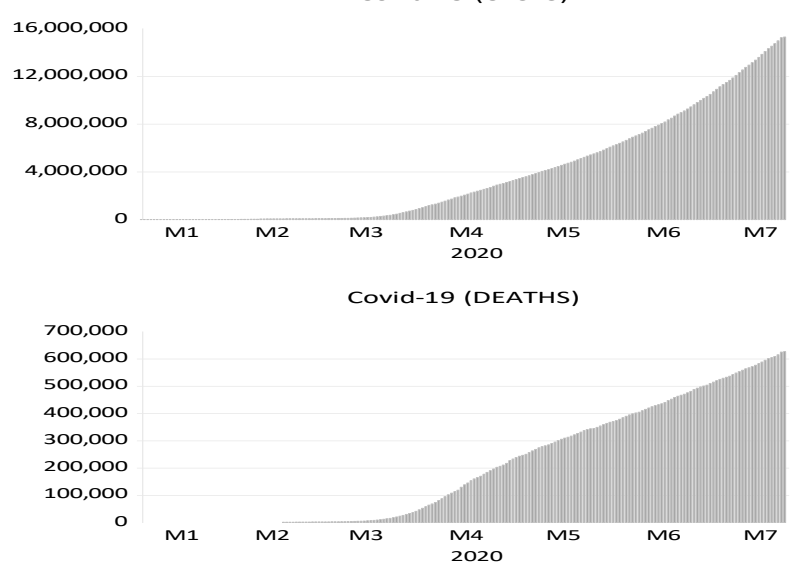

Source: Own elaboration 
Figure 2 shows the evolution of European markets, in levels, in the period from December 31st, 2019 to July 23rd, 2020, which is a period of considerable complexity, due to understanding the outbreak of the global pandemic (Covid-19). Most markets show structure breaks in February and March 2020. These results are validated by the authors Heliodoro et al. (2020), Dias, Pardal, et al. (2020), Dias, Heliodoro, Alexandre, et al., (2020a), Dias, Heliodoro, and Alexandre (2020), Dias et al. (2020), that show significant structural breaks in financial markets due to the impact of the 2020 global pandemic.

Figure 2. Evolution, in levels, of the 8 financial markets, in the period from 12/31/2019 to
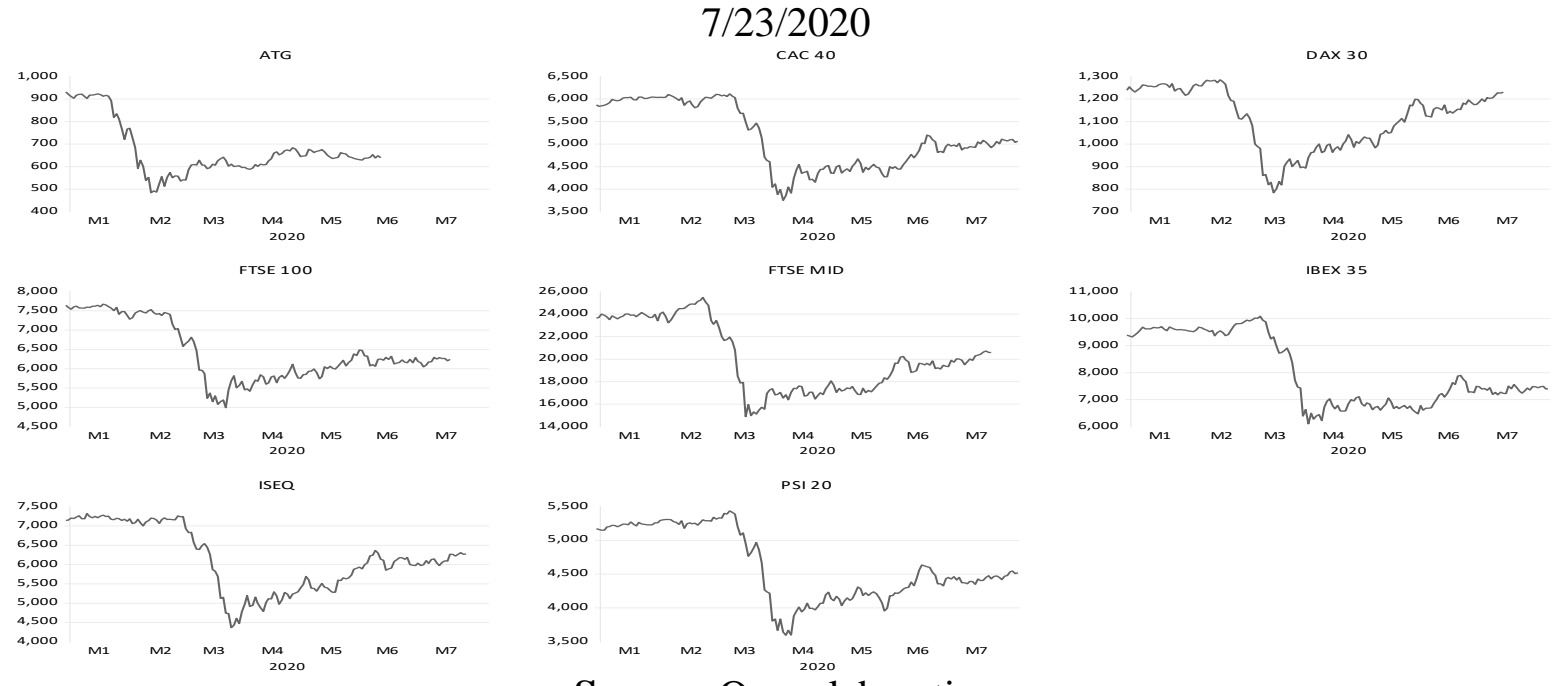

Source: Own elaboration

Figure 3 shows the evolution, in returns, of Europe's 8 financial markets. In all series, there is a relatively high dispersion around the average, as well as a relatively synchronized behavior between the data series. Graphical analysis shows the existence of high volatility, especially in February, March and April 2020.

Figure 3. Evolution, in $\%$ of the differences, of the 8 financial markets, in the period from $12 / 31 / 2019$ to $7 / 23 / 2020$

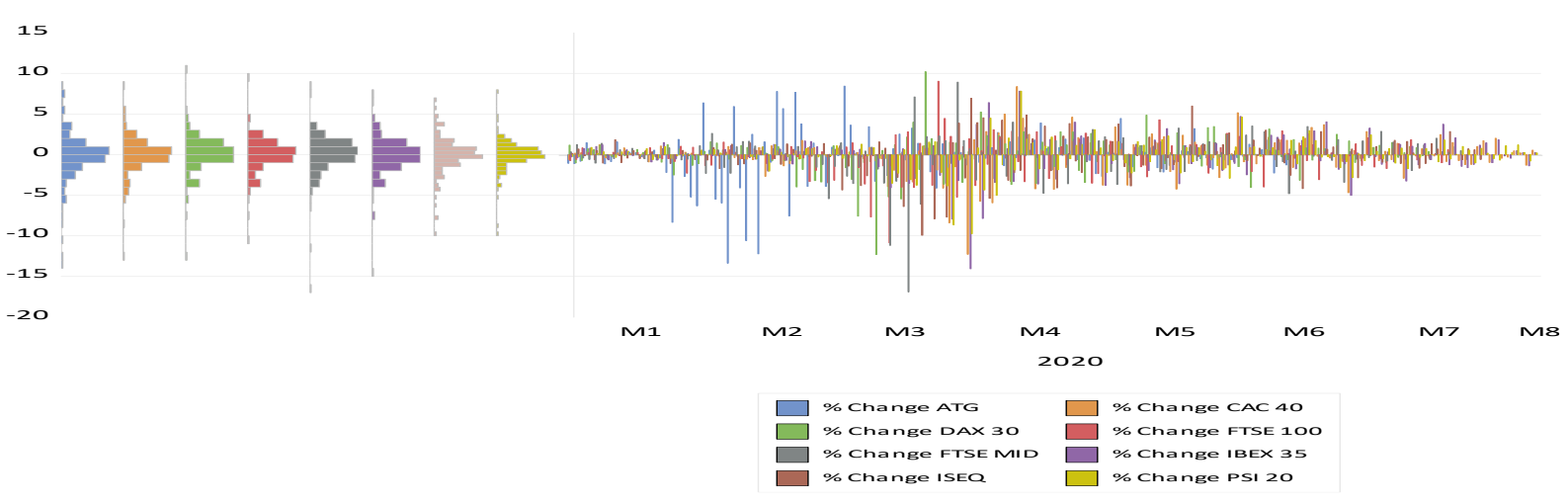

Source: Own elaboration.

Table 2 shows the main descriptive statistics on the returns of the eight European financial markets, as well as the Jarque-Bera adherence test. Analyzes of descriptive statistics show that profitability shows negative daily averages, except for the German (DAX 30) and Ireland (ISEQ) markets. The Greek market has the largest standard deviation, while the Italian market 
has the highest levels of kurtosis and asymmetry. Additionally, the coefficients of asymmetry and kurtosis are statistically different from those of a normal distribution.

Table 2. Descriptive statistics, on returns, of the 8 financial markets in Europe, in the

Complete period

\begin{tabular}{|l|c|c|c|c|c|c|c|c|}
\hline & ATG & CAC 40 & DAX 30 & FTSE 100 & FTSE MID & IBEX 35 & ISEQ & PSI 20 \\
\hline Mean & -0.001538 & -0.000477 & 0.000467 & -0.000692 & -0.000197 & -0.001036 & $4.30 \mathrm{E}-05$ & -0.000452 \\
\hline Std. Dev. & 0.027084 & 0.021336 & 0.020510 & 0.019336 & 0.023779 & 0.022028 & 0.021069 & 0.017225 \\
\hline Skewness & -1.521235 & -1.456190 & -1.299364 & -1.177540 & -2.900081 & -1.828632 & -1.076405 & -1.521948 \\
\hline Kurtosis & 10.92967 & 11.74239 & 14.13378 & 11.50055 & 24.02861 & 15.09658 & 8.213614 & 13.94787 \\
\hline Jarque-Bera & $598.1297 * * *$ & $704.0564 * * *$ & $1083.840 * * *$ & $645.1387 * * *$ & $3945.543 * * *$ & 1324.203 & $* * * 263.8107 * * *$ & $1070.629 * * *$ \\
\hline Sum & -0.306004 & -0.094967 & 0.093023 & -0.137761 & -0.039151 & -0.206089 & 0.008563 & -0.089869 \\
\hline Sum Sq. Dev. & 0.145238 & 0.090134 & 0.083291 & 0.074025 & 0.111956 & 0.096072 & 0.087891 & 0.058748 \\
\hline Observations & 199 & 199 & 199 & 199 & 199 & 199 & 199 & 199 \\
\hline
\end{tabular}

Source: Own elaboration.

Figure 4. Stability tests carried out on the residues of the 8 financial markets in Europe, in the Complete period
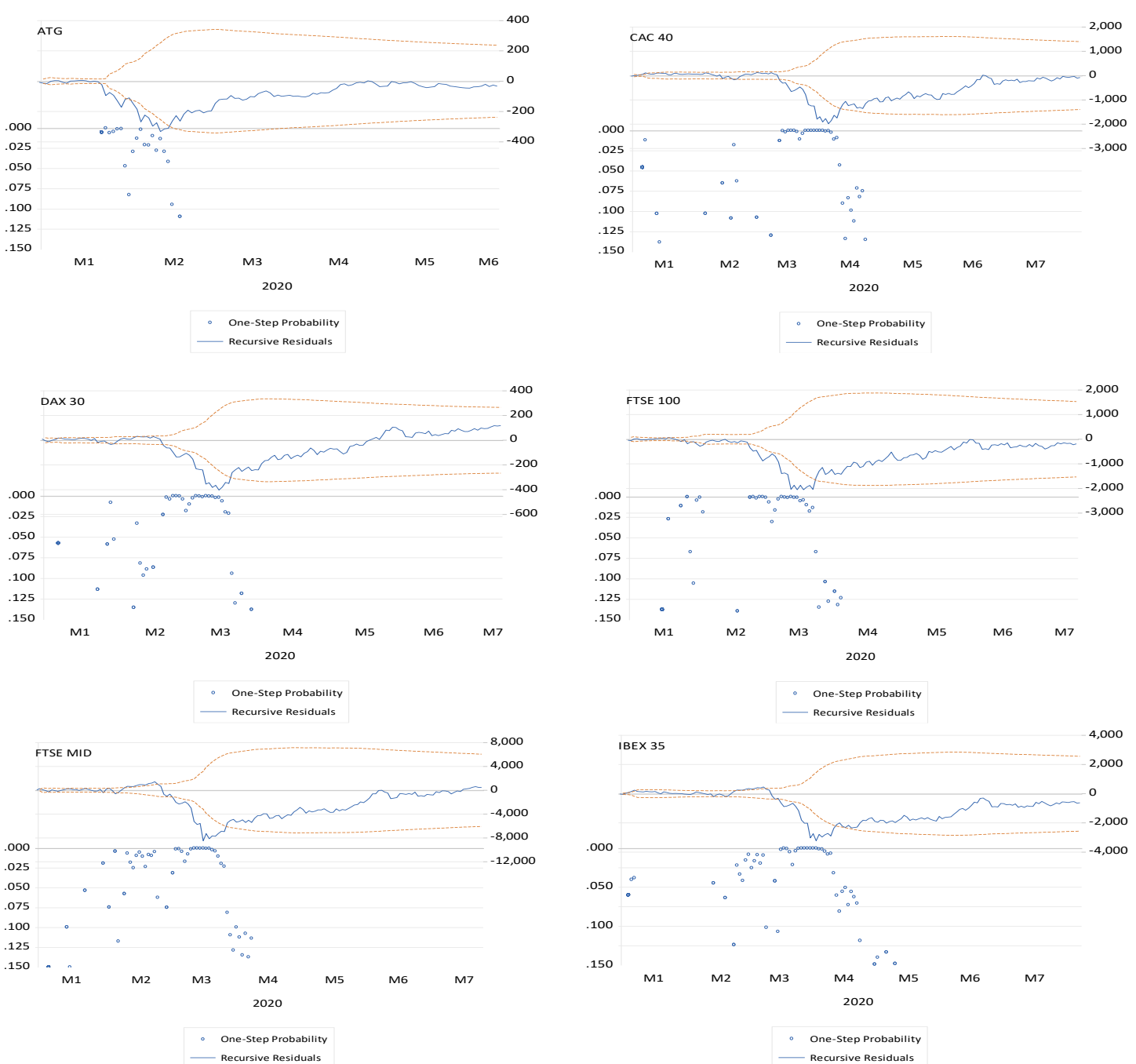

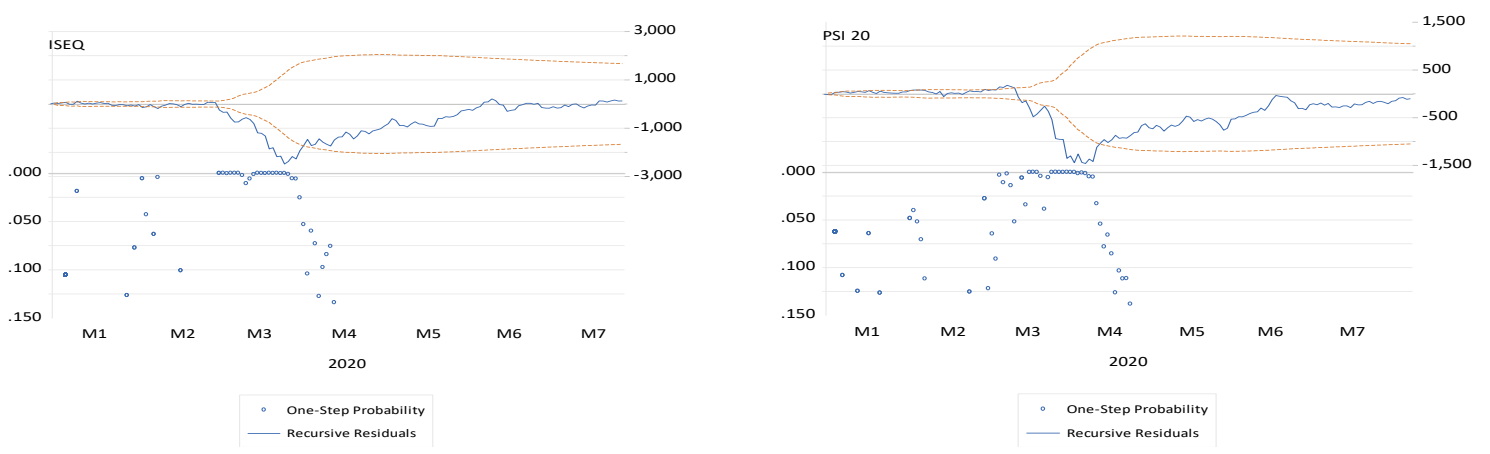

Source: Own elaboration

Figure 4 shows the stability tests carried out on the residues of the European stock markets, to corroborate the presence of structural breaks. The determination of the structural break is relevant, as it affects potentially like that of the unit-roots. Through graphical analysis, we can assess the existence of disturbances in variance. Additionally, when examining the graphs and the $95 \%$ probability limits, we verified the existence of a violation of the probability limits, thus, the time series show unstable behavior.

Table 3 shows the results of Clemente et al. (1998) which identifies structural breaks, mostly in March 2020, resulting from the global pandemic (Covid-19). However, when we evaluate the synchronizations between the Covid-19 data series and the financial markets in Europe, we find that the structure breakdowns mostly occur in April 2020, it means, different from the breakdown of the market itself; this shows, that the pandemic has a very significant impact on these financial markets. These findings are corroborated by the authors Liu, Manzoor, Wang, Zhang and Manzoor (2020) that show significant structural breaks resulting from the Covid-19 outbreak.

Table 3. Unit root tests with structural breaks of Clemente et al. (1998), in returns, referring to the 8 financial markets in Europe, Complete period

\begin{tabular}{|c|c|c|}
\hline Index & t-stat & Break Date \\
\hline ATG & $-12.57(0)^{* * *}$ & $05 / 02 / 2020$ \\
\hline CAC 40 & $-13.53(0)^{* * *}$ & $31 / 03 / 2020$ \\
\hline DAX 30 & $-12.82(0)^{* * *}$ & $10 / 03 / 2020$ \\
\hline FTSE 100 & $-13.91(0)^{* * *}$ & $12 / 03 / 2020$ \\
\hline FTSE MID & $-14.61(0)^{* * *}$ & $17 / 03 / 2020$ \\
\hline IBEX 35 & $-13.12(0)^{* * *}$ & $02 / 04 / 2020$ \\
\hline ISEQ & $-12.46(0) * * *$ & $19 / 03 / 2020$ \\
\hline PSI 20 & $-13.19(0)^{* * *}$ & $26 / 03 / 2020$ \\
\hline
\end{tabular}

Note: Lag Length (Automatic Length based on SIC). Break Selection: Minimize Dickey-Fuller t-statistic. The lateral values in parentheses refer to lags. ***.**.*. represent significance at $1 \% .5 \%$ and $10 \%$. respectively.

Source: Own elaboration.

The results of the Gregory-Hansen test can be seen in Table 4, which shows the synchronizations between the Covid-19 (confirmed cases), Covid-19 (deaths) data and the European financial markets. Covid-19 data (confirmed cases) integrate with the Covid-19 data series (deaths), with the Spanish market (IBEX 35), Greece (ATG), and Italy (FTSE MID). However, the Covid-19 data series (deaths) is synchronized with the Covid-19 data (confirmed cases), with the markets of Germany (DAX 30), France (CAC 40), Ireland (ISEQ), Italy ( FTSE MID), United Kingdom (FTSE 100) and Portugal (PSI 20), just does not synchronize with the Greek market (ATG). We can easily see that the Covid-19 data series (deaths) have a major 
impact on the financial markets in Europe, and we also find that most of the structural breakdowns in integration occur, mostly, in April 2020, differently from breaking of the market itself (March 2020). These results are partially confirmed with the authors' Zeren and Hizarci (2020) that show that the global cases of the outbreak have cointegration relations with the SSE, KOSPI and IBEX35 markets, but not with the FTSE MIB, CAC40, DAX30 markets.

Table 4. Gregory-Hansen tests, period Covid (31/12/2019 to 23/07/2020)

\begin{tabular}{|l|c|c|c|c|c|}
\hline \multicolumn{1}{|c|}{ Markets } & t-statistic & Method & Lags & Break Date & Results \\
\hline Covid-19 (cases) / Covid-19 & $-5.06 * *$ & Regime & 5 & $30 / 05 / 2020$ & Integration \\
\hline Covid-19 (cases) / IBEX 35 & $-5.49 * * *$ & Trend & 0 & $21 / 06 / 2020$ & Integration \\
\hline Covid-19 (cases) / ATG & $-5.21 * *$ & Trend & 0 & $21 / 06 / 2020$ & Integration \\
\hline Covid-19 (cases) / FTSE MID & $-5.55^{* * *}$ & Regime & 0 & $17 / 04 / 2020$ & Integration \\
\hline $\begin{array}{l}\text { Covid-19 (deaths) / Covid-19 } \\
\text { (cases) }\end{array}$ & $-6.78^{* * *}$ & Trend & 0 & $21 / 04 / 2020$ & Integration \\
\hline Covid-19 (deaths) / DAX 30 & $-5.45^{* * *}$ & Trend & 0 & $18 / 04 / 2020$ & Integration \\
\hline Covid-19 (deaths) / CAC 40 & $-5.23 * *$ & Regime & 0 & $17 / 04 / 2020$ & Integration \\
\hline Covid-19 (deaths) / ISEQ & $-5.47 * * *$ & Regime & 0 & $18 / 04 / 2020$ & Integration \\
\hline Covid-19 (deaths) / FTSE MID & $-5.89 * * *$ & Regime & 0 & $17 / 04 / 2020$ & Integration \\
\hline Covid-19 (deaths) / FTSE 100 & $-5.16^{* *}$ & Regime & 0 & $18 / 04 / 2020$ & Integration \\
\hline Covid-19 (deaths) / PSI 20 & $-5.19 * *$ & Regime & 0 & $17 / 04 / 2020$ & Integration \\
\hline
\end{tabular}

Notes: The asterisks $* * *, * *, *$ indicate statistical significance at $1 \%, 5 \%$ and $10 \%$, respectively.

Source: Own elaboration.

To analyze the significance of the causal relationships between the financial markets under analysis, the VAR Granger Causality / Block Exogeneity Wald Tests model was applied. To determine the number of lags to include in the causality tests, we used the HQ criterion (Hannan-Quinn information criterion) which suggests 2 lags (see table 5).

Table 5. VAR Lag Order Selection Criteria

\begin{tabular}{|c|c|c|c|c|c|c|}
\hline Lag & LogL & LR & FPE & AIC & SC & HQ \\
\hline $\mathbf{2}$ & 5552.948 & 423.7915 & $2.41 \mathrm{e}-37$ & -55.94710 & -52.37130 & $\mathbf{- 5 4 . 4 9 8 7 4} *$ \\
\hline
\end{tabular}

\section{Source: Own elaboration}

In figure 5 we can see the autocorrelation in the residues with 2 lags in the financial markets, however, in the Covid-19 data series (confirmed cases and deaths) this is not the case. A smaller number of lags increases the degrees of freedom, a greater number of lags decreases the problems of autocorrelation, given that we estimate a VAR with 4 lags for the data series of the European financial markets.

In Table 6 we can verify the results of the VAR Residual Serial Correlation LM Tests; we performed a VAR estimation with 4 lags, and then we performed the autocorrelation test at 5 lags; the null hypothesis was not rejected, which proves that the model does not present autocorrelation in residues, which indicates that the model presents a robust estimation. 
Figure 5. VAR Residuals Test


Source: Own elaboration

Table 6. VAR Residual Serial Correlation LM Tests

\begin{tabular}{|c|c|c|c|c|c|c|}
\hline Lag & LRE* stat & df & Prob. & Rao F-stat & df & Prob. \\
\hline 1 & 205.3774 & 100 & 0.0000 & 2.165009 & $(100,978.4)$ & 0.0000 \\
\hline 2 & 132.8881 & 100 & 0.0155 & 1.350990 & $(100,978.4)$ & 0.0158 \\
\hline 3 & 165.5520 & 100 & 0.0000 & 1.710690 & $(100,978.4)$ & 0.0000 \\
\hline 4 & 134.4604 & 100 & 0.0123 & 1.368044 & $(100,978.4)$ & 0.0125 \\
\hline $\mathbf{5}$ & $\mathbf{1 0 3 . 2 7 1 4}$ & $\mathbf{1 0 0}$ & $\mathbf{0 . 3 9 1 3}$ & $\mathbf{1 . 0 3 4 5 8 6}$ & $\mathbf{( 1 0 0 , 9 7 8 . 4 )}$ & $\mathbf{0 . 3 9 3 5}$ \\
\hline
\end{tabular}

Source. Own elaboration

The results of Granger's causality tests are shown in table 7, referring to Covid-19 data (confirmed cases and deaths), and the financial markets under analysis. The causality tests show 2 bidirectional causal relationships between confirmed cases and deaths from the Covid19 virus. However, there were no clashes between Covid-19 data (cases and deaths) and the financial markets.

Table 7. Granger / Block Exogeneity Wald Tests, in the Full Period

\begin{tabular}{|l|l|l|}
\hline & Covid-19 (cases) & Covid-19 (deaths) \\
\hline Covid-19 (cases) & $* * * * * * *$ & $3.84(4) * * *$ \\
\hline Covid-19 (deaths) & $16.02(4) * * *$ & $* * * * * * *$ \\
\hline ATG & $0.02(4)$ & $0.06(4)$ \\
\hline CAC 40 & $0.11(4)$ & $0.10(4)$ \\
\hline DAX 30 & $0.08(4)$ & $0.04(4)$ \\
\hline FTSE 100 & $0.13(4)$ & $0.09(4)$ \\
\hline FTSE MID & $0.10(4)$ & $0.02(4)$ \\
\hline IBEX 35 & $0.12(4)$ & $0.04(4)$ \\
\hline ISEQ & $0.28(4)$ & $0.17(4)$ \\
\hline PSI 20 & $0.34(4)$ & $0.18(4)$ \\
\hline
\end{tabular}

Note: Column markets "cause" online markets. The lateral values in parentheses refer to lags. ***. **. *. represent significance at $1 \% .5 \%$ and $10 \%$ respectively.

Source: Own elaboration.

\section{CONCLUSION}

The general conclusion to be retained and sustained by the results obtained, through tests carried out with econometric models, demonstrates that the global pandemic has a significant 
impact on the memory properties of the analyzed financial markets. The results indicate that the covid-19 data (confirmed cases and deaths) are mostly integrated with the financial markets analyzed. The causality tests show 2 bidirectional causal relationships between confirmed cases and deaths from the Covid-19 virus. However, there were no shocks between Covid-19 data (cases and deaths) and the financial markets. As a final discussion, we consider that investors should rebalance their portfolios, at least while this pandemic lasts, and adjust their portfolios in hedging and/or sovereign debt assets, to mitigate risk and improve the efficiency of their wallets.

\section{REFERENCES}

Alexandre, P., Dias, R., \& Heliodoro, P. (2020a). EUROPEAN FINANCIAL MARKET INTEGRATION: A CLOSER LOOK AT GOVERNMENT BONDS IN EUROZONE COUNTRIES. Balkans Journal of Emerging Trends in Social Sciences, 3(1), 78-86. https://doi.org/10.31410/balkans.jetss.2020.3.1.78-86

Alexandre, P., Dias, R., \& Heliodoro, P. (2020b). HOW LONG IS THE MEMORY OF THE REGION LAC STOCK MARKET? Balkans Journal of Emerging Trends in Social Sciences, 3(2). https://doi.org/10.31410/balkans.jetss.2020.3.2.131-137

Alexandre, P., Heliodoro, P., \& Dias, R. (2019). THE CONTAGION EFFECT IN EUROPE: A DCC GARH APPROACH. In 5th LIMEN Conference Proceedings (part of LIMEN conference collection) (pp. 73-79). https://doi.org/10.31410/limen.2019.73

Ali, M., Alam, N., \& Rizvi, S. A. R. (2020). Coronavirus (COVID-19) - An epidemic or pandemic for financial markets. Journal of Behavioral and Experimental Finance. https://doi.org/10.1016/j.jbef.2020.100341

Ashraf, B. N. (2020). Stock markets' reaction to COVID-19: Cases or fatalities? Research in International Business and Finance. https://doi.org/10.1016/j.ribaf.2020.101249

Clemente, J., Montañés, A., \& Reyes, M. (1998). Testing for a unit root in variables with a double change in the mean. Economics Letters, 59(2), 175-182. https://doi.org/10.1016/S0165-1765(98)00052-4

Dias, R., da Silva, J. V., \& Dionísio, A. (2019). Financial markets of the LAC region: Does the crisis influence the financial integration? International Review of Financial Analysis, 63(February), 160-173. https://doi.org/10.1016/j.irfa.2019.02.008

Dias, R., Teixeira, N., Machova, V., Pardal, P., Horak, J., \& Vochozka, M. (2020). Random walks and market efficiency tests: Evidence on US, Chinese and European capital markets within the context of the global Covid-19 pandemic. Oeconomia Copernicana, 11(4). https://doi.org/10.24136/OC.2020.024

Dias, R., \& Carvalho, L. C. (2020). Hedges and safe havens: An examination of stocks, gold and silver in Latin America's stock market. Revista de Administração Da UFSM, 13(5), 1114-1132. https://doi.org/10.5902/1983465961307

Dias, R., Heliodoro, P., \& Alexandre, P. (2019). Risk transmission among stock markets in LAC Region: financial crises impact, 91-97.

Dias, R., Heliodoro, P., \& Alexandre, P. (2020). Efficiency of Asean-5 Markets: An Detrended Fluctuation Analysis. Mednarodno Inovativno Poslovanje $=$ Journal of Innovative Business and Management, 12(2), 13-19. https://doi.org/10.32015/jibm.2020.12.2.13-19

Dias, R., Heliodoro, P., Alexandre, P., Santos, H., \& Farinha, A. (2021). Long memory in stock returns: Evidence from the Eastern European markets. SHS Web of Conferences, 91. https://doi.org/10.1051/shsconf/20219101029

Dias, R., Heliodoro, P., Alexandre, P., \& Vasco, C. (2020a). FINANCIAL MARKET INTEGRATION OF ASEAN-5 WITH CHINA: AN ECONOPHYSICS APPROACH. In 4th EMAN Conference Proceedings (part of EMAN conference collection) (pp. 17-23). 
https://doi.org/10.31410/eman.2020.17

Dias, R., Heliodoro, P., Alexandre, P., \& Vasco, C. (2020b). The shocks between oil market to the bric stock markets: A generalized VAR approach, 25-31.

Dias, R., Heliodoro, P., Teixeira, N., \& Godinho, T. (2020). Testing the Weak Form of Efficient Market Hypothesis: Empirical Evidence from Equity Markets. International Journal of Accounting, Finance and Risk Management, 5(1), 40. https://doi.org/10.11648/j.ijafrm.20200501.14

Dias, R., Pardal, P., Teixeira, N., \& Machová, V. (2020). Financial Market Integration of $\begin{array}{llll}\text { ASEAN-5 with China. } & \text { Littera }\end{array}$ https://doi.org/10.36708/littera_scripta2020/1/4

Dias, R., \& Pereira, J. M. (2021). The Impact of the COVID-19 Pandemic on Stock Markets. International Journal of Entrepreneurship and Governance in Cognitive Cities, 1(2), 5770. https://doi.org/10.4018/ijegcc.2020070105

Gregory, A. W., \& Hansen, B. E. (1996). Residual-based tests for cointegration in models with regime shifts. Journal of Econometrics, 70(1), 99-126. https://doi.org/10.1016/03044076(69)41685-7

Gujarati, D. N. (2004). Basic Econometrics. New York. https://doi.org/10.1126/science.1186874

Heliodoro, P., Dias, R., \& Alexandre, P. (2020). Financial Contagion Between the Us and Emerging Markets: Covid-19 Pandemic Case. 4th EMAN Selected Papers (Part of EMAN Conference Collection), 1-9. https://doi.org/10.31410/eman.s.p.2020.1

Jarque, C. M., \& Bera, A. K. (1980). Efficient tests for normality, homoscedasticity and serial independence of regression residuals. Economics Letters, 6(3), 255-259. https://doi.org/10.1016/0165-1765(80)90024-5

Jawadi, F., Chlibi, S., \& Cheffou, A. I. (2019). Computing stock price comovements with a three-regime panel smooth transition error correction model. Annals of Operations Research. https://doi.org/10.1007/s10479-018-2805-3

Lee, E.-J. (2017). Intra- and inter-regional portfolio diversification strategies under regional market integration: Evidence from U.S. global banks. International Review of Financial Analysis. https://doi.org/10.1016/j.irfa.2017.08.001

Liu, H., Manzoor, A., Wang, C., Zhang, L., \& Manzoor, Z. (2020). The COVID-19 outbreak and affected countries stock markets response. International Journal of Environmental Research and Public Health. https://doi.org/10.3390/ijerph17082800

Pardal, P., Dias, R., Šuleř, P., Teixeira, N., \& Krulický, T. (2020). Integration in Central European capital markets in the context of the global COVID-19 pandemic, 15(4). https://doi.org/10.24136/eq.2020.027

Moagar-Poladian, S., Clichici, D., \& Stanciu, C. V. (2019). The comovement of exchange rates and stock markets in Central and Eastern Europe. Sustainability (Switzerland). https://doi.org/10.3390/su11143985

Özer, M., Kamışl1, M., \& Kamışl1, S. (2016). The Analysis of Volatility Spillovers between the German and Central and Eastern European (CEE) Stock Markets by Using Frequency Domain Causality Test. In Europe and Asia: Economic Integration Prospects.

Salisu, A. A., Ndako, U. B., Adediran, I. A., \& Swaray, R. (2020). A fractional cointegration VAR analysis of Islamic stocks: A global perspective. North American Journal of Economics and Finance. https://doi.org/10.1016/j.najef.2019.101056

Zeren, F., \& Hizarci, a. (2020). The Impact of Covid-19 Coronavirus on Stock Markets: Evidence From Selected Countries. Muhasebe ve Finans Incelemeleri Dergisi. https://doi.org/10.32951/mufider.706159 